\title{
Aikuisväestön koulutus 2000
}

Aikuiskoulutuksen tulee suunnittelussakin olla koulutusjärjestelmän täysivaltainen jäsen. Näin on ajatellut valtioneuvoston asettama koulutussuunnittelun neuvottelukunta raportissaan Väestön koulutus 2000 (komiteanmietintö 1988: 28), joka luovutettiin opetusministereille 1.9.1988. On toki heti lisättävä, että kysymyksessä ei tälläkään kertaa ole kaikentyyppinen koulutus eikä kaiken huomioon ottava suunnittelu: mietintö koskee niin sanottua ammatillisesti eriytyvää koulutusta ja sille asetettavia määrällisiä tavoitteita.

On kuitenkin monesti todettu asia - ja myös tosiasia - että määrällinen ja laadullinen suunnittelu eivät ole toistensa vastakohtia, vaan pikemmin kääntöpuolia. Kun koulutussuunnittelun neuvottelukunta ehdottaa, että niin ja niin monen aikuisopiskelijan olisi voitava aloittaa vuonna 2000, taustalla on arvioita ja tietoja, pohdintoja ja asettamuksia. Jatkuvan koulutuksen ideoitakaan ei ole unohdettu.

Esittelen seuraavassa ehdotuksia aikuiskoulutuksen kannalta. Viitteellisesti käsittelen myös jatkotoimia sekä vapaan sivistystyön ja muun yleissivistävän aikuiskoulutuksen asemaa ja roolia.

\section{Pääkategorioita ja pohjatietoja}

Aikuiskoulutusta koskevat ehdotukset on laadittu ajatellen ensinnäkin perus- ja uudelleenkoulutusta, toiseksi jatkokoulutusta ja kolmanneksi täydennyskoulutusta; lisäkoulutuksen piiriin kuuluva uudelleenkoulutus on siis käsitelty peruskoulutuksen yhteydessä. Hyväksi on käytetty myös jaottelua omaehtoiseen koulutukseen, henkilöstökoulutukseen ja työllisyyskoulutukseen.

Koska polttopisteessä on 'ammatillisesti eriytyvä' koulutus, on pidetty luonnollisena että keskeisiä pohjatekijöitä ovat tiedot ja arviot siitä, miten työelämä ja ammatit kehittyvät. Neuvottelukunta on teettänyt ammattirakenneennusteen, jonka empiirisenä aineistona ovat olleet muun muassa väestölaskentatiedot. Kun vuoteen 2000 mennessä varsinkin terveys- ja sosiaalityön, johtavan teknisen ja hallinnollisen työn, kulttuuri- ja järjestystyön sekä kaupallisen työn tekijöiden tarve kasvaa, valmistus- työn, alkutuotannon työn, teknisten tukitöiden, varasto- ja kuljetustyön sekä huolto- ja asennustyön tekijöiden tarve pienenee.

Aikuisväestön koulutuksen kannalta on ollut tärkeätä pohjustaa suunnittelua myös tiedoilla siitä, millainen koulutus eri-ikäisillä ja eri aloilla toimivilla on entuudestaan. Jotakin kertonee jo se, että nykyisin miltei puolet työikäisestä väestöstä ja noin 40 prosenttia työllisistäkin on enintään perusasteen koulutuksen varassa.

\section{Perus- ja uudelleenkoulutus}

Perus- ja uudelleenkoulutuksen tarvetta arvioidessaan neuvottelukunta on lähtenyt siitä, että koko peruskoulun päättävälle nuorisoikäluokalle taataan mahdollisuudet ammattisuuntautuneeseen koulutukseen. Vuonna 2000 tämä merkitsee noin 65000 aloittajan määrää. Lisäksi noin 20 prosentille ikäluokasta eli 13000 hengelle on varattava mahdollisuudet jatkaa opiskelua peruskoulutuksessa. Kaikkiaan nuoruusiän ammatillisesti eriytyvän peruskoulutuksen aloittajia olisi tarvearvion mukaan 78000 .

Aikuisväestön ammatillisesti eriytyvän perus- ja uudelleenkoulutuksen vuosituhannen vaihteessa aloittavien tarve puolestaan on arvioitu noin 50 000:ksi, mikä vastaa noin kahta prosenttia työvoimasta. Kun nykyinen taso on noin 26000 aloittajaa, tarpeen tyydyttäminen vaatii koulutuksen kaksinkertaistamista. Sekä kokonaisarviota että ammattilohkoittaisia tarvearvioita laadittaessa on otettu huomioon se koulutettujen tarve, jota ei kyetä tyydyttämään nuoruusiän koulutuksen avulla.

Ammatillisesti єriytyvän perus- tai uudelleenkoulutuksen vuonna 2000 aloittavien tarve olisi täten yhteensä 128 000. Neuvottelukunta on laatinut avaimet, joita käyttäen voidaan siirtyä ammattilohkoittaisesta ja -ryhmittäisestä koulutustarpeesta koulutusjärjestelmän kielellä määrittyvään koulutustarpeeseen. Neuvottelukunta operoi viidellä koulutuslohkolla. Ne ovat alkutuotanto, tekniikka, kaupalliset palvelut, yhteiskuntapalvelut ja kulttuuri. Kukin lohko on jaoteltu edelleen pienempiin kategorioihin.

Tarpeiden määrittämisestä on lopulta edetty tavoitteiden määrittämiseen. Hyväksi on käytetty laskelmien lisäksi harkintaa.

Yksinkertaisinta ja selkeintä on antaa tauluk- 
kojen puhua. Koulutusmuodoittain perus- ja uudelleenkoulutuksen määrälliset tavoitteet käyvät ilmi taulukosta 1 .

Taulukko 1. Perus- ja uudelleenkoulutuksen vuonna 2000 aloittavat koulutusmuodoittain

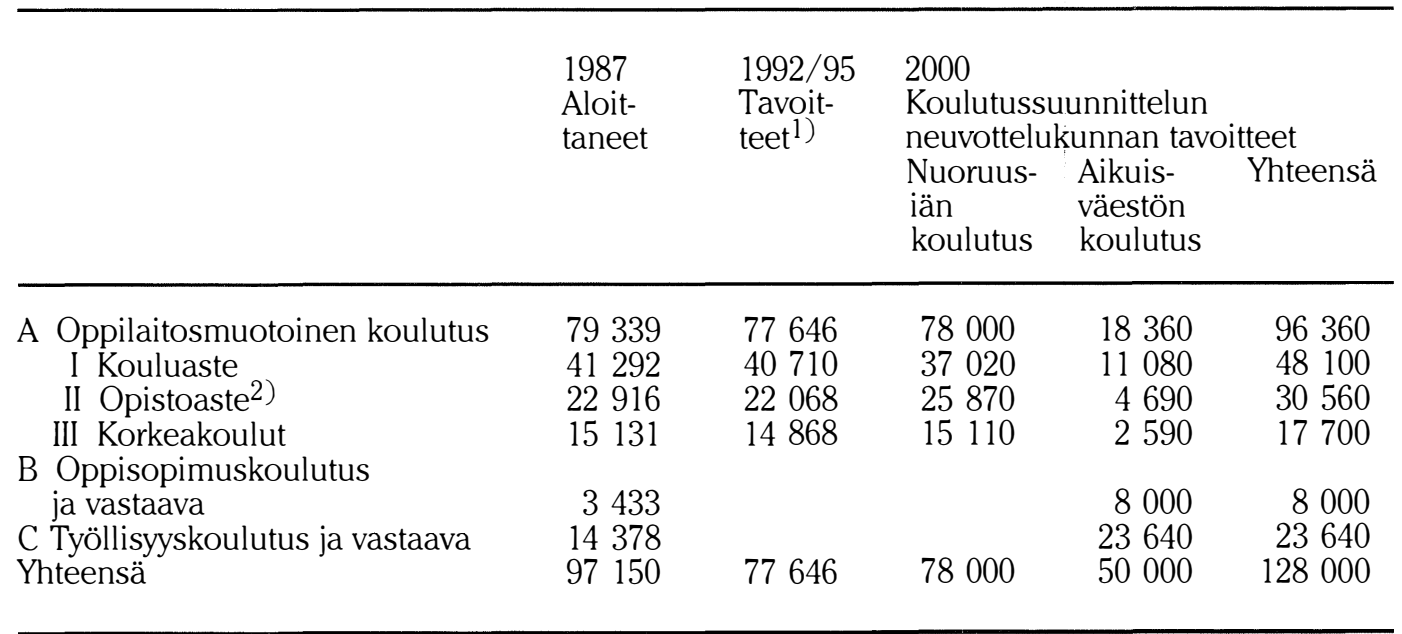

1) Valtioneuvoston hyväksymät tavoitteet. Koskee myös taulukkoja 2-4.

2) Sisältää ammatillisen korkea-asteen.

Aikuisväestön koulutus esiintyy kiinteästi muun koulutuksen yhteydessä. Mukana ovat keskiasteen ja siihen rinnastettava ammatillinen koulutus ja korkeakoulutus (oppilaitosmuotoinen koulutus), oppisopimus- ja vastaava koulutus sekä työllisyys- ja vastaava koulutus. Kuten taulukon lakonisista merkinnöistä on todettavissa, oppisopimuskoulutus on käsitelty kokonaan aikuiskoulutuksen yhteydessä. Neuvottelukunta on pitänyt oppisopimuskoulutusta tärkeänä henkilöstökoulutuksen muotona.

Koulutuslohkoittain samat tavoitteet ovat esitettävissä taulukosta 2 ilmenevällä tavalla.

Taulukko 2. Perus- ja uudelleenkoulutuksen vuonna 2000 aloittavat koulutuslohkoittain

$1987 \quad$ 1992/95 2000

Aloit- Tavoit- Koulutussuunnittelun

taneet teet neuvottelukunnan tavoitteet

Nuoruus- Aikuis- Yhteensä

iän väestön

koulutus koulutus

\begin{tabular}{lrrrrr}
\hline 1 Alkutuotanto & 5939 & 5825 & 4190 & 4600 & 8790 \\
2 Tekniikka & 35394 & 26695 & 27150 & 17750 & 44900 \\
3 Kaupalliset palvelut & 32749 & 21395 & 23340 & 16750 & 40090 \\
4 Yhteiskuntapalvelut & 15609 & 16720 & 16060 & 8000 & 24060 \\
5 Kulttuuri & 7459 & 7011 & 7260 & 2900 & 10160 \\
Yhteensä & 97150 & 77646 & 78000 & 50000 & 128000 \\
\hline
\end{tabular}


Tärkeätä, kasvavaa alaa koskevan tavoitteenasettelun esimerkiksi voidaan poimia yhteis- kuntapalvelujen koulutuslohkoon liittyvät ehdotukset (taulukot 3 ja 4).

Taulukko 3. Yhteiskuntapalvelujen koulutuslohkon perus- ja uudelleenkoulutuksen vuonna 2000 aloittavat koulutusmuodoittain

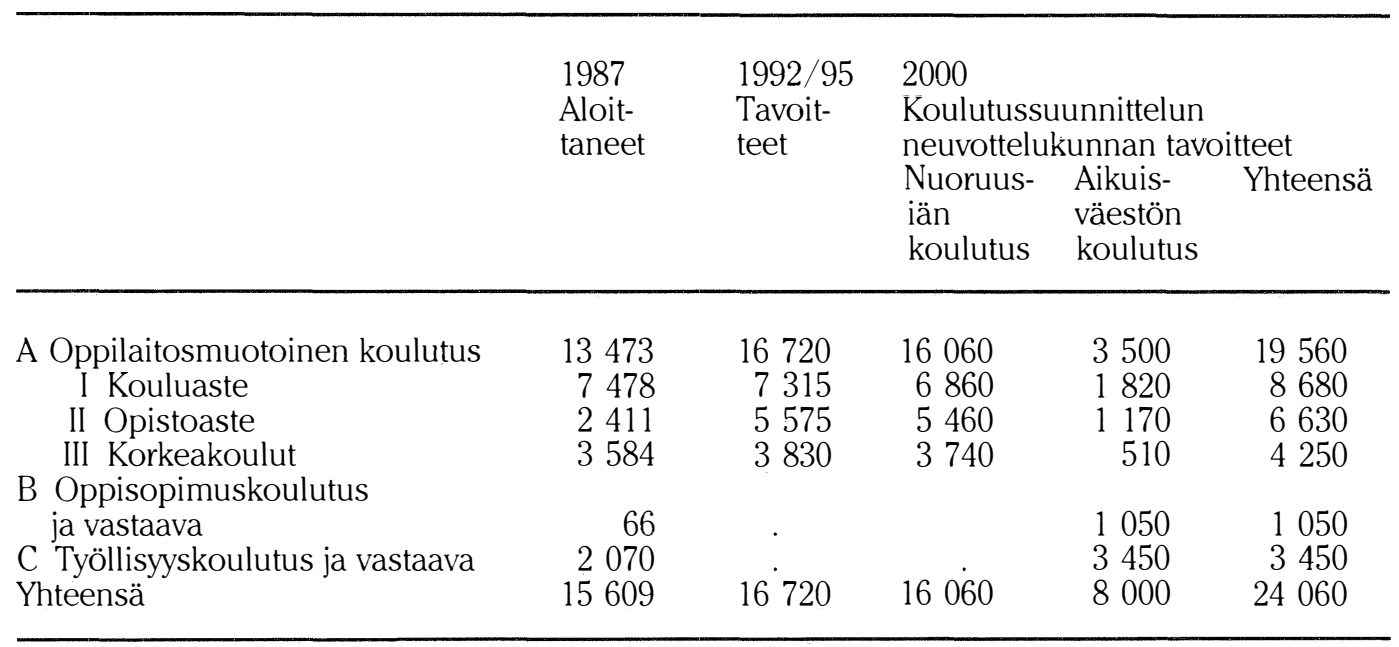

Taulukko 4. Yhteiskuntapalvelujen koulutuslohkon oppilaitosmuotoisen perus- ja uudelleenkoulutuksen vuonna 2000 aloittavat koulutusryhmittäin ja -asteittain

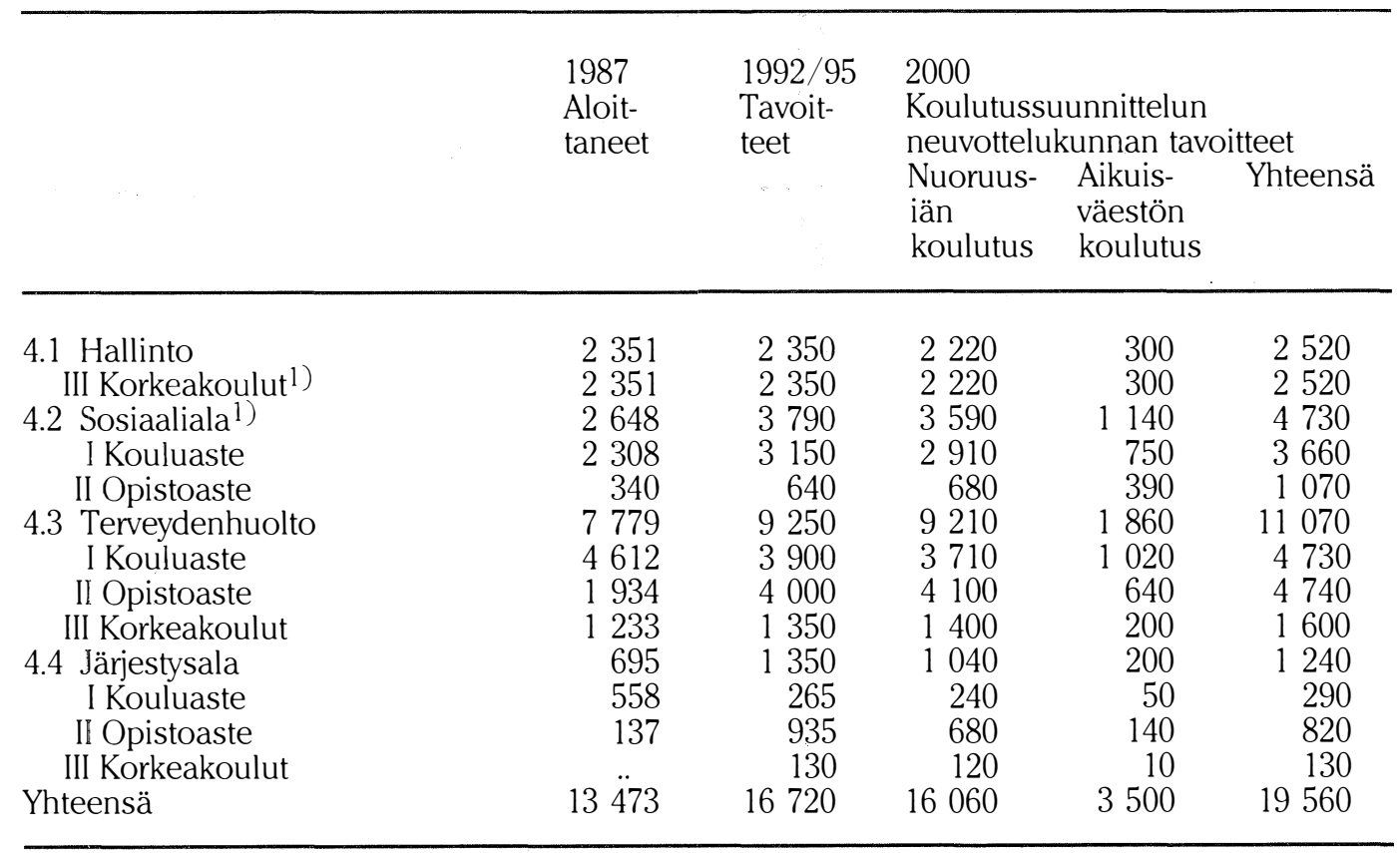

1) Sosiaalialan korkeakouluasteinen koulutus sisältyy luokkaan 4.1. 
esitetty taulukossa 5 . Kokonaistavoite 30000 aloittajaa on noin kolmanneksen nykyistä aloittajien määrää suurempi. Taulukosta ilmi

Jatkokoulutusta on käsitelty seurannaisena. Kysymyksessä on kulloisenkin alan pitemmälle vievä koulutus, joka - kuten perus- ja uudelleenkoulutus - on yleensä tarkoitettu johtamaan tutkinnon luonteiseen tulokseen. Ajatuksena on ollut, että kaikille aloille luodaan toimiva jatkokoulutuksen järjestelmä.

Jatkokoulutuksen päätyyppien tavoitteet on käyvän lisäksi on haluttu painottaa myös sellaista täydennyskoulutusta, jota nykyisin toteutetaan korkeakoulujen pitkäkestoisina täydennyskoulutusohjelmina. Tieteellistä jatkokoulutusta puolestaan tulee neuvottelukunnan mukaan kehittää siten, että vuosituhannen vaihteessa suoritetaan vähintään 800 tohtorin tutkintoa vuodessa.

Taulukko 5. Jatkokoulutuksen vuonna 2000 aloittavat koulutuslohkoittain ja -muodoittain

Koulutussuunnittelun neuvottelukunnan tavoitteet

Keskiasteen Työllisyys- Henkilöstö-

jatko-

linjat $^{1)}$

koulutus

ja vastaava koulutus ${ }^{2)}$

Yhteensä

\begin{tabular}{lrrrr}
\hline 1 Alkutuotanto & 700 & 800 & 400 & 1900 \\
2 Tekniikka & 3700 & 4400 & 2600 & 10700 \\
3 Kaupalliset palvelut & 3700 & 3600 & 2100 & 9400 \\
4 Yhteiskuntapalvelut & 2450 & 2400 & 1400 & 6250 \\
5 Kulttuuri & 450 & 800 & 500 & 1750 \\
Yhteensä & 11000 & 12000 & 7000 & 30000
\end{tabular}

1) Tarkoitettu sekä koulu- että opistoasteen tutkinnon suorittaneille. Enimmäkseen omaehtoista koulutusta. Osa henkilöstökoulutusta.

2) Muu kuin keskiasteen jatkolinjoilla annettava henkilöstökoulutus.

\section{Täydennyskoulutus}

Täydennyskoulutukselle ei ehdoteta täsmällisiä numeerisia tavoitteita. Neuvottelukunta arvioi kuitenkin, että henkilöstökoulutuksena annettavan täydennyskoulutuksen tarve on vuosituhannen vaihteessa todennäköisesti vähintään viisi päivää työllistä kohti vuodessa; nykyisin koulutuspäiviä on Tilastokeskuksen laskelmien mukaan runsaat kaksi palkansaajaa kohti. Jos lähtökohdaksi otetaan viiden päivän tarvearvion mukainen taso, vuonna 2000 tulisi olla tarjona noin 13 miljoonaa henkilöstökoulutuksena annettavan täydennyskoulutuksen päivää. Jos lähtökohtana olisi seitsemän päivää, kokonaismäärä olisi noin 18 miljoonaa koulutuspäivää.

Neuvottelukunta suosittaa tähänastisten ja tulevien tarveselvitysten hyödyntämistä ja muistuttaa, että kysymyksessä ovat suurelta osin asiat, jotka kuuluvat neuvottelu- ja sopimusmenettelyjen piiriin. Muun muassa omaehtoisen täydennyskoulutuksen tarpeiden ja tavoitteiden määrittämiseksi neuvottelukunta odottaa Tilastokeskukselta tuoretta selvitystä aikuiskoulutukseen osallistumisesta; edellisen tiedot koskevat vuosien 1979-80 tilannetta.

\section{Työvoimamenetelmä, funktionaalinen ote}

'Koulutus 2000' on esimerkki niin sanotun työvoimamenetelmän soveltamisesta. Ainakaan Suomessa työhön ja ammatteihin sekä niiden muuttumiseen liittyvä suunnittelu ja ennustaminen ja toisaalta koulutussuunnittelu eivät ole erkaantuneet, toisin kuin nähtävästi monissa muissa maissa (tästä erkaantumisesta ks. R. V. Youdi - K. Hinchliffe (toim.): Forecasting skilled-manpower needs: the experience of eleven countries. Unesco: International Institute for Educational Planning. Brussels 1985).

Puhtaasti määrällisten tekijöiden rinnalla 
'Koulutus 2000' -raportissa kulkevat varsin 'laadulliset' tekijät: koetetaan paneutua yhteiskunnan tulevaan kehitykseen ja tehdä siitä koulutusta koskevia päätelmiä. Ote on ollut pikemmin 'funktionaalinen' kuin organisaatiokeskeinen. Tavoitteenasettelun lähtökohtiin on kuulunut koulutuksen eri lajien joustava hyödyntäminen ja yhdistely: "Nuoruusiän peruskoulutus sekä aikuisväestön perus- ja uudelleenkoulutus, jatkokoulutus ja täydennyskoulutus ovat kokonaisuus, jonka osatekijöiden keskinäisiä, myös määriin liittyviä suhteita voidaan käytännössä muunnella. Eri koulutusmuodot ja osittain -asteet voivat joustavasti korvata toisiaan." Mietinnössä on varauduttu siihen - asiaa tähdentämättä - että esimerkiksi keskiasteen koulutuksen rakenne saattaa ajan mittaan muuttua.

\section{Jatkotoimet}

Jotta Suomi saisi tarvitsemansa koulutetun väen, väki tarvitsemansa koulutuksen ja ammatillisesti eriytyvä aikuiskoulutus ansaitsemansa aseman reaalimaailmassa, kohti tavoiteltua tasoa olisi syytä lähteä pikaisesti. Näin oltaisiin selkeästi hallitusohjelman linjoilla ja jatkettaisiin valtioneuvoston jo vuonna 1978 aikuiskoulutuksen suunnittelu- ja kehittämisperiaatteista sekä vuosina 1987 ja 1988 ammatillisen aikuiskoulutuksen rahoittamisesta ja kehittämisestä tekemien päätösten tiellä.

\section{Entä yleissivistävä aikuiskoulutus?}

Ammatillisen ja toisaalta yleissivistävän aikuiskoulutuksen välillä kulkee eri tavoin havaittavissa oleva juopa. Mutta kuten 'Koulutus 2000' -raportissa todetaan, ammatillinen ja yleissivistävä koulutus eivät aikuisen näkökulmasta ole erillisiä alueita.

Tarvittaisiinko vapaan sivistystyön ja muun yleissivistävän aikuiskoulutuksen tueksi uudenlaista kvantitatiivistakin suunnittelua? Menetelmät voisivat olla vain osaksi työvoimapohjaisia. Kysymykseen voisi tulla rohkea, vapautta kunnioittava ennakointi ja kokonaisuuksien etsintä. Kohdattavana on yhtä lailla ansiotyötä tekevien ja tavoittelevien kuin muidenkin ihmisten maailma. 